\title{
Management of Learning Technique on Lesson Termodinamika on Department Mechanical Engineering Maritime Inonesia Academy Medan
}

\author{
Maria Magdalena ${ }^{1} \quad$ Fatolosa Telaumbanua $^{2}$ \\ 1.Citizenship Education, STKIP Riama Medan, Indonesia \\ 2.Maritime Indonesia Academy, Medan
}

\begin{abstract}
This research is a development research to develop the design of the right learning technique in the process of learning on the subject of Thermodynamics at the Department of Mechanical Engineering Academy of Indonesia Maritime Medan. The population in this study is all students in the Department of Mechanical Engineering, while the research sample used is the students who are active in taking thermodynamics courses that is as much as 4 classes (100 people) in the second half (even) Academic Year 2017/2018. The method used in this research is the method of Research and Development, while the techniques in data retrieval used is through observation, documentation, interviews, and questionnaires. All the techniques in data collection in this class are used to see the success in the learning process. From the results of research and discussion conducted, learning techniques show that student learning outcomes tend to be high. The average value of student learning outcomes is 87.71 . As many as $100 \%$ of students can pass the threshold for thermodynamics course that is $\geq 60$. There are $2 \%$ of students are categorized enough, $6 \%$ of students are categorized capable and $92 \%$ of students are categorized as very capable.
\end{abstract}

Keywords: Management Learning Technique, Thermodynamics and Learning Outcomes DOI: $10.7176 / \mathrm{JEP} / 10-2-06$

\section{Introduction}

The purpose of national development is to educate the life of the nation. One of the efforts in fulfilling the responsibility to educate the life of the nation, the government, the family, and the community work together in the implementation of education. Education is held from elementary level up to university (PT). One indicator of the success of a department and students in addition to understanding is the result of learning. Long study period causes the input output ratio to be small, and there is a buildup of students in a major. One cause of the low value of students at the Department of Mechanical Engineering Academy of Maritime Indonesia Medan based on the author's observation is a monotonous learning techniques. The instructional techniques given so far using the pulpit teaching techniques (conventional) or the expository approach are supported with LCD and white board media, and structured tasks. This technique is less motivating students in following the lecture, because this technique is no different from the delivery of other courses in general. According to the authors of this course must have important outcomes include: students have the ability to follow and understand the material well, so have good learning outcomes, students are able to follow the lectures well, and students are able to think more critically scientifically. One of the internal factors suspected to be the causal factor is the students' initial perception of the course of Thermodynamics, some argue that the thermodynamics course is difficult, difficult, boring, confusing and must present something new and it is considered difficult, in addition to their limited knowledge and reading materials, and learning systems that do not demand the ability of students. According to the authors need to change learning techniques that can change these perceptions and motivate students and provide a deep understanding of the process in following the lectures. So it can be said that the results of the learning techniques provided so far have not been satisfactory. This is also shown from the final grade of the course which is still not satisfactory. Learning is a process or how to get people to learn. While learning is an effort to increase knowledge or change the behavior, and the learning process includes aspects of knowledge, attitude, and psychomotor (Gimin, 2004). The purpose of the learning process in general is to master the material learned by students well. In other terms achieved mastery learning or students are able to fully master the learning materials learned. But in reality not every implementation of learning is able to achieve it. Some students have found it difficult to learn. Learning difficulties derived from the learning system is one of them due to the low quality of learning, the quality of learning that tends to center on the lecturer (teacher centered teaching method). Such learning tends to be dogmatic, dominant of rote, and insecure creativity or freedom of thinking of students. According Rooijakkers (1991), there are some things to note, so that educators have the expected efficiency, among others: preparation of lessons or courses, implementation of learning, and feedback. Lecturers should have maximum planning before teaching starting from teaching preparation, preparing props (multi media) used; flexible or widespread implementation that is to adapt to changing conditions or a dynamic environment; and must evaluate or monitor the feedback from the learning process, so it can be known how far 
the optimization of the learning process undertaken. Thus the learning process is a guide for the success of a teacher to what which he taught. According to Rooijakkers (1991), there are some indicators for the learning process to run better and can meet the target with indicators, namely: students must progress, students should appreciate the material presented, and educators get satisfaction. Furthermore, there are several steps towards effective learning that is: to set clear course objectives; selecting and determining teaching materials; overcoming the first day meeting; improve sophistication lectures; increase student involvement; multiply discussions with and between students; discuss case studies; assigning assignments for papers and oral presentation, and testing and assessing students.

According to Gimin (2004), there are three important aspects that should be the attention of a lecturer in order to effectively process learning, among others: planning, classroom management, and evaluation toward the achievement of the established goals. Planning in this case is to design the teaching-learning process. According to Kemp (1985), there are four keys in the process of teaching design: for whom, what do you want, how is the best learners, dan how do you determine the learning has been achieved. The four elements are closely related and influence each other's success in learning.

Absolute management or class management is done, a lecturer can divide lectures into three divisions namely: introduction as a means of motivator, the core as a means of conveying the subject matter, and the closing section as a means of conclusion and delivery of information for the next lecture. Evaluation to know how far the success of learning process both to student and to lecturer. Assessment of students through oral and written evaluation, while the lecturer through the questionnaire given to the students by looking at the responses they provide with indicators tailored to the purpose of the lecture.

Based on the above opinions, the lecturer's job as an educator is to facilitate the learning process with meaningful and relevant knowledge for the learners, namely: to provide an opportunity for learners to find and apply their own ideas, and awaken the students to apply their strategies in learning.

\section{Research Methods}

In conducting this research, the authors first conducted a literature review and pre-survey of research and collect information including literature review, learning observation that aims to analyze and determine the basic competencies that must be owned by students of Mechanical Engineering Department of Indonesian Academy of Maritime Medan who take thermodynamics course on semester II Academic Year 2017/2018.

Mechanism and research design and analysis of research data as follows.

1. Field Prasurvey:

a. By collecting information that includes literature review to analyze and determine the thermodynamic competence that must be possessed by students covering the description of skills, objectives, and learning strategies.

b. Planning starts from the data obtained in the field to be the basis of the development of learning techniques.

c. Analyze the data.

2. Learning technique test focuses on evaluation of learning process:

a. Data were collected through observation sheets and questionnaires distributed to lecturers and students to find out the advantages and disadvantages of learning techniques.

b. Data analysis is statistically descriptive.

3. Learning technique test focus on evaluation of student learning outcomes.

a. Data were collected through observation sheets and questionnaires distributed to lecturers and students to find out the advantages and disadvantages of learning techniques.

b. Provide a thermodynamic learning result test.

c. Data analysis is statistically descriptive and comparing student learning outcomes to competency standards that must be achieved.

For the survey step begins with collecting information includes literature review, learning observation that aims to analyze and determine the competence of thermodynamics course that must be owned by students of Mechanical Engineering Department of Indonesian Maritime Academy Medan which includes skill, outcomes, learning strategies. Activities undertaken as field surveys are directed to the analysis of the need for the development of instructional techniques. Planning starts from the data obtained in the field to be the basis of the development of learning techniques. Then the discussion with curriculum experts and learning developers in designing the development of early forms of learning techniques. Step test of learning technique is to conduct early field trials that focused on the evaluation of the learning process to determine the weaknesses and advantages of learning techniques developed through opinions of students and lecturers, then revised and discussed with curriculum experts and learning developers to find reference products. The revised results are then tested to be implemented again, in addition to focusing on the evaluation of the learning process to determine the weaknesses and advantages of learning techniques developed through the opinions of students and 
lecturers are also evaluated on student learning outcomes through postest. The final step is socialization and dissemination or dissemination of information about learning techniques to improve the competence of thermodynamics courses at the Department of Mechanical Engineering Maritime Academy Indonesia Medan. In addition it is intended that the results of this study can be utilized by various parties, especially those associated with learning competency course Thermodynamics.

\section{Results and Discussion}

Management of learning technique on learning course of Termodinamika semester II Academic Year 2017/2018 for Engineering Department students of Mechanical Engineering Academy of Indonesia Medan, starting with:

1. Explain the competence and sub-competence to be achieved by the students. Thermodynamic lecture contracts are distributed to all students taking thermodynamics courses, to facilitate students' understanding of a one-semester learning plan. In the lecture contract that is distributed to the students there is a competence to be achieved by the students if the students have followed the course of Thermodynamics with the learning technique. For the formation of study groups students are welcome to choose their own friends who they are find it appropriate to work together in discussions for both classroom and group learning outside of college. This is done to make it easier for students to communicate in an effort to complete group work papers assigned to each group. While the material for each group is distributed to the students by way of drawing, so that all students feel there is no difference between the groups with each other.

2. In group learning in the class the students sit in groups according to the group which is still related to the topic of learning being discussed. Groups that present group assignments are welcome to select moderators from their own group members, so that each group can foster good cooperation in each learning groups that have been formed.

3. Interactive is implemented after students complete the presentation task in front of the class. Starting from the student's study group present the task, the observation sheet has started to be filled, with clear assessment criteria indicators, making it easy to fill out the presentation assessment sheet. The pangamat group begins to fill in the observation sheet without being disturbed by the interactive discussions in the classroom. Interactive between groups of presenters with observer groups, if necessary, lecturers are allowed to provide direction or align opinions if necessary. Besides it also students can be interactive to the lecturers and classmates about the material and exercises provided. After completion of the group study presentation session, the study group assigned to the presentation makes a conclusion about the learning materials.

4. Lecturers collect observation sheets from observers and groups from senior students. After that the lecturers provide reinforcement about the material that has been discussed together. Then the lecturer reminded again about the material to be discussed next week.

5. The result of management technique of learning of thermodynamics in the effort of increasing the competence of the students of Mechanical Engineering Department of Indonesian Academy of Maritime Medan showed a significant improvement. The average of the students' learning outcomes on the learning of the Therodinamika course is 87.71 . Based on Table 1 below, it can be seen the percentage of student learning outcomes.

Table 1. Percentage of student learning outcomes

\begin{tabular}{|c|c|c|c|l|}
\hline No. & Value Interval & Amount Mahasiswa & Percentage (\%) & \multicolumn{1}{|c|}{ Category } \\
\hline 1 & $0-19$ & 0 & 0 & Unable \\
\hline 2 & $20-39$ & 0 & 0 & Less Capable \\
\hline 3 & $40-59$ & 2 & 2 & Enough \\
\hline 4 & $60-79$ & 6 & 6 & Capable \\
\hline 5 & $80-100$ & 92 & 92 & Very Capable \\
\hline
\end{tabular}

Student learning data shows that $100 \%$ of students pass the threshold for thermodynamics course, since the graduation limit is $\geq 60$. There are $2 \%$ of the students are categorized enough, $6 \%$ of students are categorized capable and $92 \%$ of the students are categorized as very capable. For more details, this can be seen in Figure 1. below. 


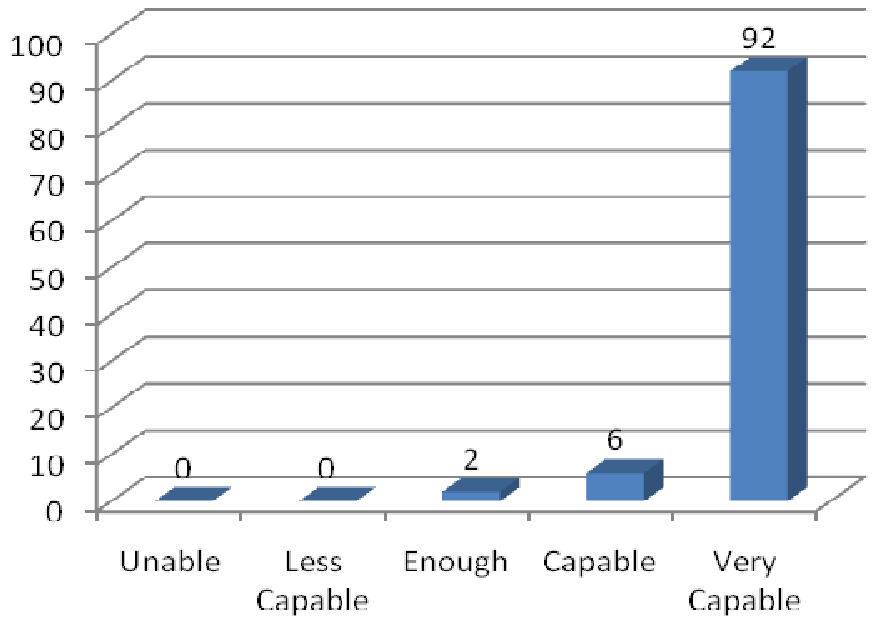

Figure 1. Percentage of student learning outcomes.

In the orientation and direction to the students, the lecturer gives a direct example of the application of Thermodynamics in everyday life. Because by looking at the direct example of the student will more quickly understand especially if faced with the problem of Thermodynamics, then the student will try to pull the problem to real life so that to finish it becomes easier for students.

Learning on the subjects of Thermodynamics using learning techniques, students should have read the material before the lecture begins lecture. This will make it easier for students to provide arguments during interactive discussions. In addition, if there is a problem of Thermodynamics related to the topic of discussion being presented by the study group students can be expressed to be discussed together to find the answer of the problem so that when interactive can take place in accordance with the lesson plan. In addition, if the problem can not be completed by the study group, the lecturer will be more easy to provide explanations related to it in an effort to improve student competence about things they have not understood, because the lecturer has known the root of the problems experienced by students. The management of Thermodynamic learning techniques applied to improve students' competence by forming a 5-member study group which they choose their own friends to work together in the learning group leads them to be more interactive in discussions. Results of field test data indicate that student achievement indicates an increase. The result of student questionnaire shows that students feel that the time is running so fast and the students like the learning model. In addition, the impact of technical accompaniment this interactive learning is the students become more confident, able to communicate orally politely because students present their group work in front of the class and do interactively between study groups that have been formed. Thus it can be said that the development of interactive learning techniques can improve student competence on learning thermodynamics.

Based on the results obtained as mentioned above, the implementation of this learning has basically achieved the goal of teaching implementation. Thesis lecturers have been able to design and implement instructional techniques to improve students' competence in thermodynamics course. Learning of thermodynamics using learning techniques makes learning a meaningful process for students, because the interactive learning process has the effect of accompaniment as students can have the nature of initiative, critical thinking, willingness to learn, polite in oral communication, the ability to analyze, solve problems, work well in teams, listening ability, time management, can be summarized and have independent properties. In addition, test results for thermodynamic learning that can be used for tests are also produced Thermodynamic learning outcomes for parallel classes. Nevertheless, the implementation of interactive learning model also still has limitations such as: learning process using learning technique requires that lecturers can motivate students to be able to present group learning tasks in front of the class, and can motivate the audience to be interactive toward the learning group being presenting his group's duties; If the student of the lecture does not have any learning preparation for the lecture material to be presented then the group's real interactive learning process will not take place; Lecturers and students already have emails, for peroses of student learning outside class hours.

The lecturer should also take the time to look at the student assignments collected via email, and provide feedback or correction on the tasks assigned by the students to improve the students' knowledge and understanding of the group tasks they have collected.

Intsruksional impact of learning techniques is the result of learning achieved directly by directing students on the expected goal is the result of student learning. Impact accompaniment is the result of other learning produced by a learning process, as a result of the creation of learning atmosphere experienced directly by the 
students without direct direction from the lecturer, such as initiative, critical thinking, willingness to learn, oral communication, the ability to analyze, solve problems, both in the team, listening, polite in speaking, time management, can summarize the material and independently.

Understanding of students who take Thermodynamics courses is enhanced by the management of learning techniques that have been improved and developed. Reality shows that students have weaknesses in terms of understanding in answering the questions given.

The applied learning technique depends not only on one method, but there are several methods applied for the achievement of the expected objectives, it depends on the competencies to be achieved in each lecture meeting or in the learning process.

Each face-to-face in the classroom, students are first handed out for the next meeting to be read before the lecture begins. Students and lecturers hold and study the same books in this course. Lecturers play a role to assist students in understanding this course, and to facilitate students' understanding, in learning process using computer media (laptop), LCD, Hand out. The result of the improvement of the instructional technique applied to the course of Thermodynamics, showed an increase in the students 'understanding reflected from the students' final values. The results of the observations during the lecture also showed a positive thing. Students look more active with group assignments. The results of questionnaires spread on the teaching and learning process showed that the students were satisfied through the evaluation result on lecturers' teaching ability and the quality of the lecture material presented.

\section{Conclusions}

From the results of research and discussion that has been done, it can be drawn some conclusions, among others:

1. Management of learning techniques in thermodynamics course at the Indonesian Maritime Academy School Medan is the process of utilizing learning tools and supporting facilities of learning thermodynamics effectively and efficiently in order to support the learning activities of the class through the development of learning techniques.

2. The learning tools in question are by awarding the lecture contract, the Course Schedule Unit, the above components are explained to the students, and the students are given an opportunity to provide input on the lecture and SAP contracts above; Implementation of the lecture contract, so as to encourage student participation. Assignment of student tasks that include routine tasks, and mini research. The supporting facilities in question are practicum facilities and infrastructures in workshops, teaching materials, internet, computer simulation, lecturer email and student email and other facilities.

3. The management of therapeutic learning technique in the Department of Mechanical Engineering of Indonesian Maritime Academy of Medan can improve students' competence through the implementation of learning techniques. The syntax of instructional techniques is orientation, group learning, interactive and transfer.

4. Educational professionalism is getting better, because applying management in the process of learning technique includes transparent planning, classroom management and process of evaluation, at the end of the lecture, so as to build a good academic atmosphere.

5. Hasil nilai mahasiswa menjadi lebih baik dengan meningkatnya mahasiswa yang memperoleh nilai A dan B (98\%), dan ketidaklulusan menjadi berkurang (0\%).

\section{Bibliography}

Borg,WR \& Gail, MD. 1983. Educational Research An Introduction. New York : Logman Inc.

De Porter, Bobby, Mark Readson, and Sarah Singer. 2004. Quantum Teaching. Practicing Quantum Learning in classrooms, Bandung: Kaifa.

De Porter, Bobby, Mike Hernacki. 2004. Quantum Learning. Familiarize the learning comfortable and fun, Bandung : Kaifa.

Dick, W \& Carey, L. 1996. The systematic design of instruction (4 ed). New York: Harper Collins Publisher.

Dryden, Gordon dan Vos, Jeannette. 2003. Revolution on how to learn the interactive (translation), Bandung.

Firdaus. 2004. Effective and Efficient Learning, Paper presented on Workshop Improving Teaching Method, Pekanbaru.

Gimin, 2004, Planning and Managing Effective Learning Process, Paper submitted on Workshop Improving Teaching Method, Pekanbaru.

Kemp, Jerrold, E. 1985. The Instructional Design Proses, Newyork, Harper \& Row, Publishers

Kuncoro, Mudrajad, 2003, Research Methods For Business and Economics, Erlangga, Jakarta.

Nazir, M., 1983, Research methods, Ghalia Indonesia, Jakarta.

Pannen, Paulina, 2001, Constructivism In Learning. PAU For Improvement and Development of Instructional Activities of Directorate General of Higher Education Department of National Education, Jakarta.

Pulungan, Ismail, 2001, Unified Quality Management, PAU For Improvement and Development of Instructional 
Activities of Directorate General of Higher Education Department of National Education, Jakarta. Rooijkkers, Ad., 1992. Teach With Success, Gramedia, Jakarta.

Toeti Sukamto. 1997. Learning Theory and Learning Models. Jakarta : Inter University Center.

Wen, S., 2003. Future of Education. Lucky Publisher.

Wina, S., 2006. Strategy of Learning-Oriented Standard Process of Education, Jakarta: Kencana Prenada Media. Yusuf Hadi Miarso. 2004. Role of Learning Technology in Organizational Learning. Jakarta: Pustekkom Diknas. 